\title{
THE INFLUENCE OF IMPAIRED FUNCTIONING OF BRAIN STRUCTURES ON THE ABILITY TO READ EMOTIONS AND SHOWING EMPATHY BY PEOPLE WITH AUTISM
}

\section{Introduction}

Autism is one of the most serious disorders of neurobiological substrate. Currently, it is said with a broad spectrum of autism, but nevertheless have still not been unequivocally established the causes of disturbances of this nature. Many researchers have indicated a number of pathomechanisms specific to autism. Among them, point out.: U. Frith on the concept of innate cognitive deficit theory B. Hermelin disturbances talking about the transfer of information, the theory of defective functioning of central coherence and theory of mind (Theory of Mind) - all cited above may result from dysfunction of work of central nervous system. However, among the concepts of strongly neurobiological substrate that can be cited: disrupted the flow of sensory stimulus, brain micro-damage or mirror neuron disorders. The above mentioned could be among them reasons of disorders in communication and social relationships and even with oneself, the ability to read emotions and showing empathy to others.

While conducting therapy with people with autism I often asked myself the question: how disturbances in perception around the world, so impaired in the transfer of information, such as inconsistencies and apparent central coherence theory of mind dysfunction, influence the inability to affect the reading other people's emotions, at the same time showing empathy to others?

Mental states are difficult to understand for people with autism, of course, they need close emotional relationships and refer such contacts, and feel compassion, but sometimes they appear only incidentally, in a unique, social hardship for reading, understanding and acceptance. In the following text, in simple and short way are traced some of the selected concepts of psychological and neurobiological, trying to find some answers to the questions posed at the same time trying to understand the behavior of my patients. 


\section{Central Coherence and Theory of Mind}

Among other things, among psychologists there are suggestions that the "theory of mind, as well as other information processing systems of reality, is growing thanks to the trend towards central coherence, that is, poor ability of the central coherence in individuals with autism could be the explanation of the theory of mental disorders. One might then conclude that all individuals with autism experience a weak development of the theory of mind" (Kruk-Lasocka, 1999, p 17). The studies show that the problems of central coherence, so characteristic of people with autism, occur regardless of the level of development of theory of mind. There was, so a hypothesis that can function independently in two different cognitive deficits (Kruk-Lasocka, 1999). In this case the pathogenesis of perception and information processing and transfer of information is not disturbed to determine malfunction theory of mind. It is true that, as theory of mind and central coherence are mechanisms implying a proper communication and social functioning, however, they are working in separate areas.

Let us therefore see how to make the transfer of received information from the environment. In a healthy person is the integration of stimuli and the fluidity of information transmission, it is true in the initial phase of the multistream transfer, but nevertheless as a result of the proper functioning of the central coherence flowing consistently. Uta Frith likens it to the river collecting information from different senses, according flowing stream (U. Frith, after: Kruk-Lasocka, 1999). Unfortunately, people with autism, "sometimes there is a serious disturbance in the above mechanism. Incentives received by the individual sensors are bonded, an abnormal intensity, break in the transfer of information or lack of movement of stimuli" (Wawrzyn, 2010, p 179-180), which also certify people with autism.

B. Rand describing his autistic world uses the expression that "seeing is not only what is perceived through the eyes, but how the image reaching the eye goes to the brain". He says that "he was repeatedly surprised by descriptions of other people for what they have heard or seen, because it was not consistent with what he saw and heard" (Rand, 2007).

Abnormalities in the perception of the world by people with autism manifest themselves in different ways. Incentives received by the individual senses flow independently of each other (due to faulty central coherence) are not integrally connected and receiving - is inconsistency of incentives, but not always and not all sensors, i.e., some of the impetus provided by the different senses can be received simultaneously - for example, stimuli received by the sense of touch and hearing may be simultaneous, and the reception of stimuli by sense of sight is later. The flow of stimuli may be disrupted as a result of various intensity, it may involve one or multiple stimulus - excessive display, or mute each of them (Wawrzyn, 2007; 2008).

The irregularities in the perception may be masking or elimination of some incentives by the second. For example, the first may "come" the picture, then 
fades, as the "comes" sound. But it can occur in such a way as T. Grandin quotes: "No sound is not stuck by my fixation. Even a sudden noise is not rescued me from my world (...). But when I stayed in the "human world", I was very sensitive to loud sounds (Grandin, 1995, p 19). It can also be followed by a time delay in the receipt of one or more relative to other stimuli such as first and "come" incentives received by a receptor (such as sight or hearing), and then follows the reception of stimuli from another receptor. It may also be loss of transmitted information on the way to the brain - or lack of perception of stimuli by the CNS" (Wawrzyn, 2010, p 180).

Observation is also selective, capture even small incentives, such as visual focus for autistic people on very small objects / items such dust particles, paying attention to the shiny object - reflecting light, or selective focusing on auditory stimuli (Delacato, 1995). Frith, quoted earlier, considers that the conviction of the child, the importance of detail in a situation may not agree with what others consider to be relevant (after: Kruk-Lasocka, 1999). Rand describing their findings, the review of "do not know why his head chooses the things on which it focuses, however, knows that they are not usually the same things that other people are going" (Rand, 2007).

Example presented, impaired cognition exemplifications of the material world are the result of defective functioning of central coherence. Such defects lead to difficulties in creating a representation of the physical/material (Frith, 2008; Kruk-Lasocka, 1999; Winczura, 2008), a person suffering from autism link directly to each given stimulus, unable to generalize individual characteristics, which results from inability to transfer intermodal information (compare theory Hermelin for impaired transfer of information) (after: Kruk-Lasocka, 1999). This fact may explain the rigidity in behavior, respect of fixed habits and rituals by people with autism (Pisula, 1999). Such behavior may be an attempt to organize the material world perceived wrong, which become a source of variability of anxiety, aggressive and/or self-aggressive behavior.

Thus, if the sick person has an impairment of perception of the physical world - matter, it will also be present in the mental perception of the world, especially mentally. However, the latter is no longer enough just well-functioning central coherence, but also is something that will explore the mental world of the same, something that will allow the creation of the representation of intangible assets: emotions, desires, beliefs, or intentions - this mechanism is Theory of Mind - theory explaining the mental states (Frith, 2008; Kruk-Lasocka, 1999; Pisula, 2000; Winczura, 2008). It has been recognized by researchers as a major component of the cognitive process. It is one of the elements of a very complex nature. Is responsible for the ability of thinking, taking place at the level of abstraction and is associated with the representation of the same mind, and one of its main features is the ability to think about thinking or the ability to imagine the state of mind of another person (U. Frith and S. Baron-Cohen, after: Winczura, 2008). And that 
theory of mind enables efficient reading other people's mental states, as well as their own minds. It allows one to apply for these states, explain and predict on the basis of human behavior (P. Steerneman after: Winczura, 2008). Children's theory of mind enables a small child understanding of messages sent by other people (in the first place by parents/guardians) - it is through the messages a person can express his emotions by doing: modulation of voice, facial expressions, gestures, glances (Wawrzyn, 2009), non-verbal communication and non-language components, including the proto-language voice, but non-verbal ways of communication (including intensity, height, pace and rhythm sent the message) (Smyczek and Szwiec, 2000).

Even infants react to human face, however, as Bowlby described are innate biological mechanisms of conditional survival (Bobkowicz-Lewartowska, 2005; Bowlby, 2007; Holmes, 2007). A child with such mechanisms responds to the arrangement of elements resembling a human face, crying and laughing (in the sixth week of life). At the same time observed children with autism, in early childhood, were stated to have their reactions such as laughter, or crying, in infancy, to be more muted than in healthy children and occur less frequently (Jaklewicz, 1993). Perhaps these are the first signs of disturbance in the functioning of theory of mind, which is determined by neurologically (Kruk-Lasocka, 1999), and is an inborn cognitive mechanism (U. Frith and F. Happe, after: Winczura, 2008) - researchers see the symptoms of autism, including early childhood autism.

Besides the ability to: understand the desires, intentions, to ask for someone's beliefs, theory of mind allows for "reading" and understanding the emotions of others (P. Steerneman, B. Huskens after: Winczura, 2008). This implies a lot of mental function: understanding, representation, abstraction, ability to pretend. It allows one to create representations of mental states (U. Frith and F. Happe, after: Winczura, 2008). Theory of mind largely determines social development, which is closely related to communication skills (both verbal and non-verbal), as reported by many researchers (L. Camaoini et al., T. Gałkowski, M. Konstantareas et. al., J. Kruk-Lasocka, E. Minczakiewicz, JG. Olley, A. Pankiewicz, I. Rapin, B. Singel, J. Surowaniec, after: Winczura, 2008). It could be hypothesized that deficits imply a theory of mind so characteristic of people with autism for the transmission of voice messages, largely without the emotional one. The inability or very limited ability in the use of the autistic people to vote is a function of modulation binding with the ability to read and express emotions, which is one component of theory of mind. Autistic person does not understand that through a system of verbal communication can also give an emotional message, and the recipient will be able to read it. Another characteristic is the saving of gestures and facial expressions as well as poor instrumental communication (A. Atwood, U. Frith and B. Hermelin, after: Winczura, 2008). One can, therefore conclude that with such a lack of expression, the autistic person does not substantially benefit from the function of the human psyche exploring the world, using primarily 
the skills to create a representation of the material world. This deficit, however, in many cases compensates for framing thinking about which he writes among other things, T. Grandin those are using phrases like: "I cannot even think the words I vividly. When I think about abstract concepts such as relationships, use of visual images, such as a glass door. Contacts with people have to be extremely polite, because the barge could break down this door" (Grandin, T., 1995, p 100).

Returning to the relationship of verbal communication with nonverbal emotional elements should be pointed out that one-year-old healthy children were aware of the impact of communication on the behavior of people close to them (Winczura, 2008). Little Children "in dialogue" with the parent/guardian (or other person) use non-verbal means of expression, read the messages and caller's emotional state and themselves transmit such signals.

Among researchers studying the communication problems of autistic children were two positions, as to which of the two - communication (Ch. Njiokiktjien, D. Ricks, M. Rutter, L. Wing, after: Winczura, 2008) or social development (K. Loveland et al., GB Mesibow, E. Schopler, after: Winczura, 2008) - the is damaged first and thus causes damage to another. Of course, specific, limited, or impaired use of verbal and nonverbal messages, or not using them leads to disturbances in social relations, but also to explore the world of mental defective, mental, or inability to use this area, it affects the normal social relationships and impaired functioning in this sphere, which in turn causes secondary deficits in language development. Although the issue is not resolved and the study did not indicate clearly which of the parts, as originally damaged is responsible for the disorder, there are strong interactions between them. It is known that communication determines the social development and vice versa.

As indicated above the level of social skills is conditioned by the development of theory of mind. The components of Theory of Mind, which lead to social development, unfortunately, in the case of people with autism are often heavily disturbed. To run the "machine" called theory of mind a lot of factors have to work well. In the further process they will intersect, tie and drive, but that this mechanism was initiated infant/child must make eye contact with a parent (or other close person). It must be supported in many subsequent interactions, which initiates the next phase of development of eye contact; the end result is a conscious belief about the child being seen by others (Piaget, 2006; Winczura, 2008). A healthy child of about 9th to 18th month of life there is a mechanism to share observations with others. Attention is divided on a particular object, which can also be a person. After taking root of this function is entering another - the central mechanism, which is the "chief" in the development of theory of mind - found in a number of components, such as desires, beliefs, intentions, the ability to simulate and identify emotions (Pisula, 2000; Winczura, 2008) - Compare: Chart 1. Child through beliefs takes the other person's point of view, and at the subsequent stage acquires the ability to think about thinking of other people. Over time (about 
6 years old) develop the ability to understand false beliefs, where falsehood and deceit are their main features. Reasoning about false beliefs can arise if the child understands his own independence between knowledge, knowledge of the partner, and reality.

However, the basic element and a prerequisite for the process of shaping a child's theory of mind is the ability to recognize emotions, which is seen as the ability to interpret his or someone's internal stat

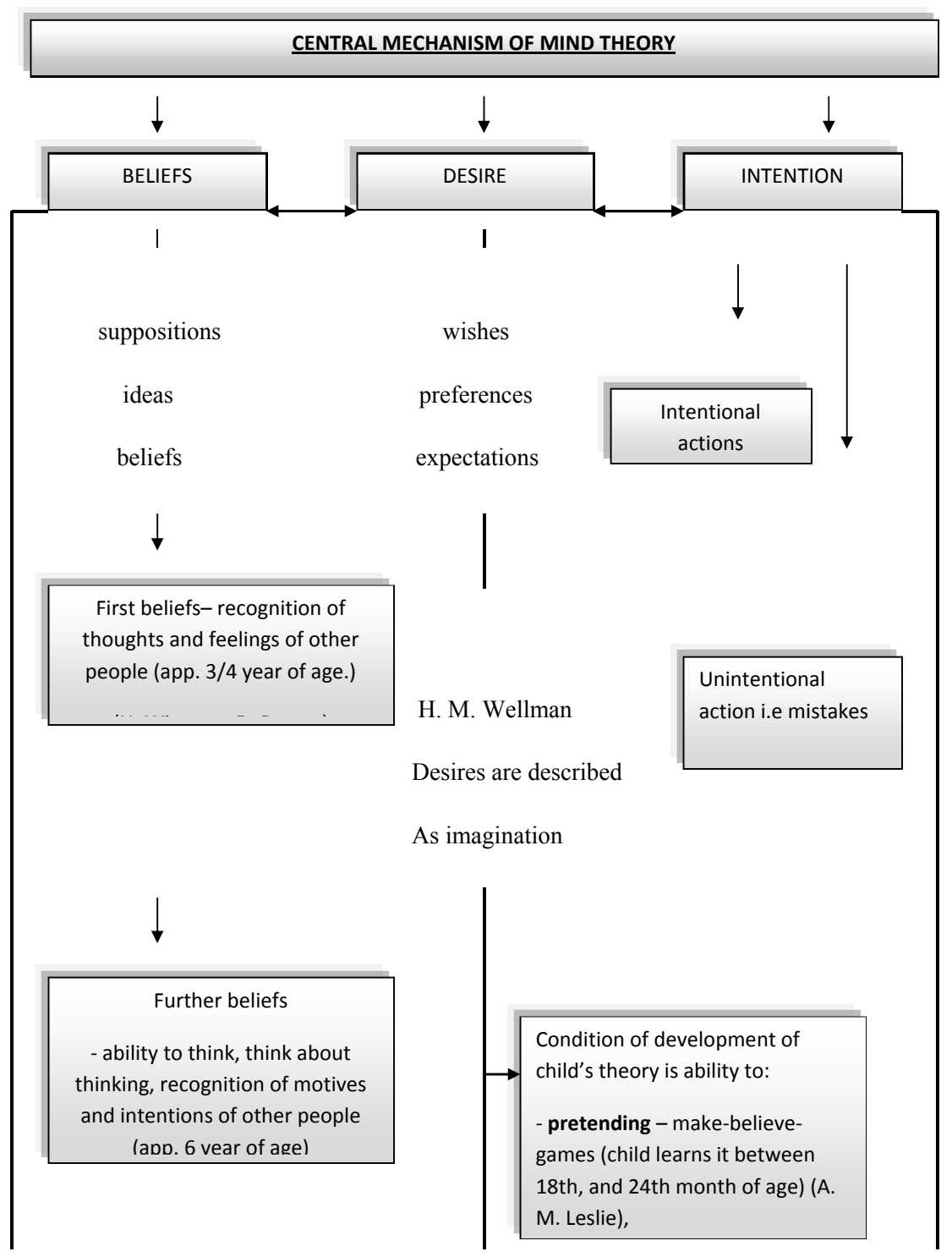



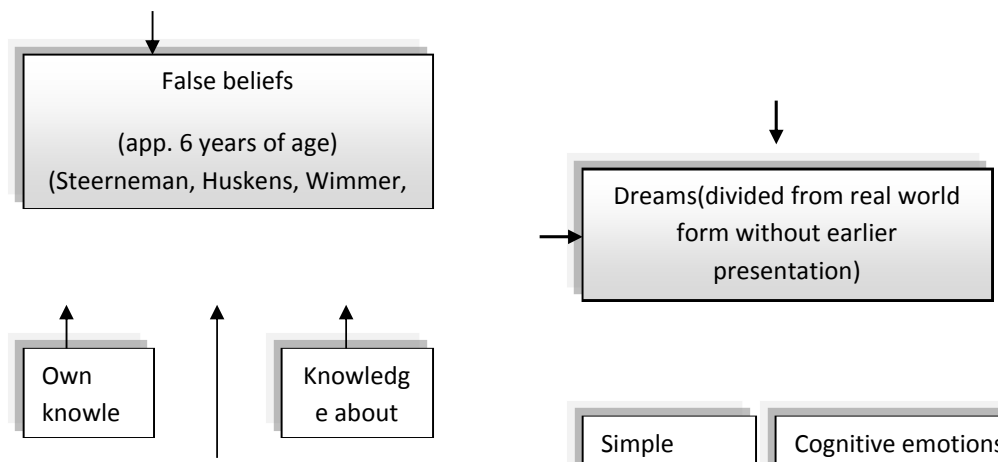

Knowledge about reality
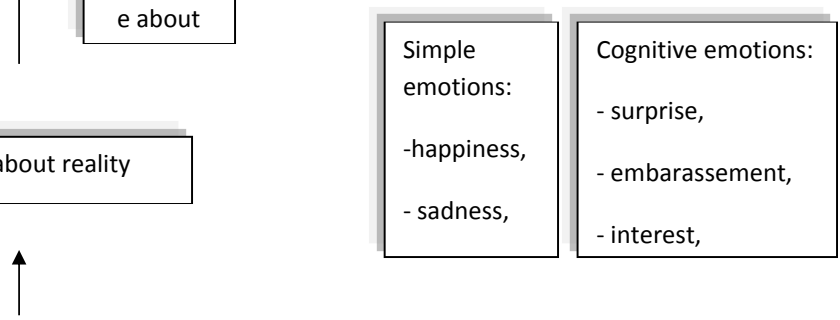

certainty about independence of these three elements
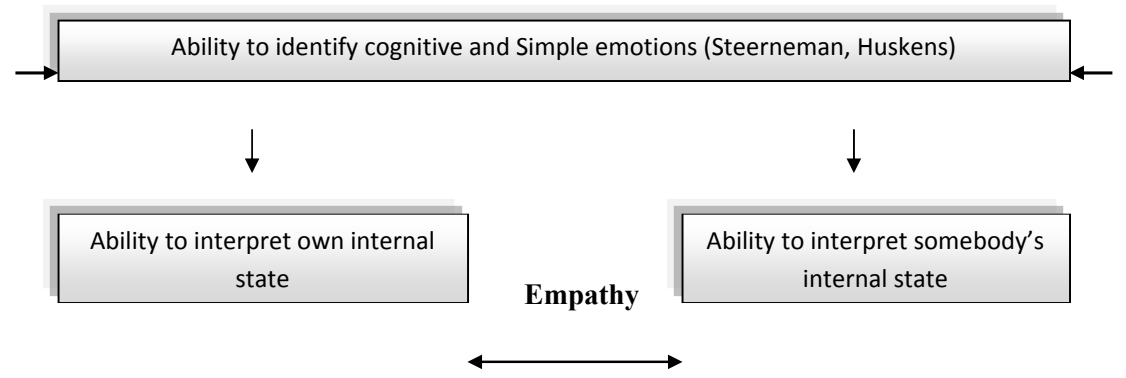

Chart 1. Components of theory of mind that create the central mechanism. Own study, 2008 on the basis of: Winczura, 2008.

As a further condition defines the understanding and the ability to pretend that this ability is reflected in the children's "make-believe games". AM. Leslie describes this mechanism as the ability to share experiences and play imaginary roles. Perceived, remembered and then used combination of abstract qualities, feelings and events taking place in the mental sphere. Leslie distinguishes three forms of pretense: the substitution of objects (using object if it were another subject), pretending to change the construction of the object (assign properties to objects which they do not have) and the imaginary simulation (this refers to the absent object as if they were present in the environment). Although the images are created, however, the mental representations of pretense, and dreams are 
separated from the real world, to whom the child does not form a representation (Winczura, 2008).

In simplified way, the central mechanism of theory of mind can be presented, which is the primary factor in the development of social skills. The child must have the ability to assign himself and others mental states in order to understand, explain and predict behavior and must understand and interpret their own and others' emotional states. This skill is needed to develop a feeling of empathy, which is not possible without this understanding. Child sympathetic in the situation of another person grasping her inner emotional state, it also follows by analogy with the state of their own, and this is due to the possibility of appeal to a previously created mental representation.

\section{The Emotional Brain Systems and Micro-damage of the Brain - the Mirror Neuron Disorders}

In this way autistic behaviors are explained by psychological theories, but neuroscientists and neuropsychologists share the opinion that the concept of emotional states is largely determined by neurobiology. The research has shown that the ability to read and understand other people's emotions is the responsibility of the relevant areas of the brain (Herzyk, 2003; Shreeve, 2005; Steuden, 2008). "Researchers distinguish three main large systems composed of many smaller structures performing specific functions in the regulation of emotion" (Herzyk, 2003, p 35). These include: the structure of the brain stem, limbic and cortical areas (Herzyk, 2003). "In studies of brain functioning systems governing emotions determined way to connect cortical areas with subcortical structures, located below and medial in relation to the cerebral cortex. Connections are very complex but not random, form a specialized pathways conducting impulses: the up and down $\rightarrow$ up $\rightarrow$ down (the road cortial-subcortial/going up and cortial-subcortial/ going down)" (Herzyk, 2003, p 35). They operate on the principle of regulation of three levels: "(the lowest level - the brain stem, the middle one - the limbic system, the highest - the cerebral cortex) forming the Autonomous-functional circuits that transmit impulses acceding and descending pathways". (Derrybery and Tucker, 1992; LeDoux, 1996; after: Herzyk, 2003, p 36). Brain stem structures located between the trunk and the new bark, among other functions controlled excitation and inhibition. The limbic system controls, but also modifies responses depending on the environmental stimuli (Herzyk, 2003; Herzyk and Krukow, 2008). "Compared with the brain stem of the limbic system responses are more varied and specific" (Herzyk, 2003, p 35), but nevertheless, as in the case of reaction of the brain stem structures are also unconscious reactions (Herzyk, 2003; Herzyk and Krukow, 2008). Areas of the cortex are the basis for awareness of emotional experiences 
with a particularly important role of the prefrontal area, with a lot of connections with the structures of the limbic system and temporal regions and parietal cortex (Herzyk, 2003). "These three systems form the circuits connected to a network of neural pathways (ascending and descending), which provides integrated and coherent activity of the body as a response to emotional stimuli and situations". (Herzyk, 2003, p 36). The functioning of the brain mechanisms of emotion also plays an important role in the hypothalamus - the expression of emotion and cerebral cortex - the experience of emotion, experiencing feelings (according to the concept of McLean) (Herzyk, 2003).

The activity of brain systems can be followed by functional imaging, eg with: positron emission tomography or magnetic resonance imaging of the brain. During this exercise, you can observe changes in activated areas (Bragdon and Gamon, 2006). Comparing the brain of a healthy person with the brain of a person with autism one can observe changes in the regions responsible for the proper processing of the perception of facial expressions and expression of emotions (Zięba, 2007). In the case of the perception of animate objects (in healthy subjects) is activated: the amygdala, fusiform and upper curve temporal furrow. The amygdala and the above-mentioned structures are activated also in recognizing emotional facial expressions (i.e. anger, fear, joy or satisfaction). In many studies have shown that the amygdala and structures orbital-medial frontal lobes are also involved in identifying the emotional significance of objects (Herzyk and Krukow, 2008). "The forehead regions of brain are responsible for theory of mind tasks, for integrating a complex situation into a meaningful whole emotionally and socially. In addition, these areas are involved in many processes of human behavior assessment, evaluation for moral behavior" (Herzyk and Krukow, 2008, p 342), they also play a key role in the evaluation of their conduct and emotional behavior of others (Herzyk and Krukow, 2008).

There are also conducted researches on children's brains. They provide information, inter alia, on the mental and emotional processes in young children who are not yet in a period of speech, and therefore are not able to issue any verbal information (from a theoretical point of view, such studies could be conducted on autistic children with profound intellectual disabilities, non-communicating). The study (conducted in Birkbeck Centre for Research in Brain and Cognitive Development in the U.S.) show that the temporal brain areas already in infants are very active during the recognition of human faces (Shreeve, 2005).

Thus, individuals with autism have a dysfunction occurring in the expression of emotions and difficulties in reading and understanding the emotional states of others is explained by impaired activity of the above areas in the brain. This is confirmed by functional studies performed using brain neuro-imaging (structural studies have shown differences in i.e., corpus callosum). In the basis states: more active (than normal) within the upper temporal gyrus, lower activity in the bottom pre-central corner in the frontal lobe and the lower activity of the amygdala. 
Neuro-imaging also possible to track the work of mirror neurons. Originally, researchers at the Università degli Studi di Parma found that "as specialized circuits of neurons in the brain to store memories of the individual, so the teams seem to mirror neurons are encoded patterns of individual actions" (Rizzolatti, Fogassi, Gallese, 2006, p 40). The researchers found that the pattern of neuronal activity is representation in the brain and not only motor function but the same intent without involving the sense of sight, only by imagination. At the same time, "that there is a direct link between the organization of intentional physical activity and the ability to understand others' intentions" (Rizzolatti, Fogassi, Gallese, 2006, p 43). This was confirmed by the study (in collaboration with the University of California at San Diego) using the functional (functional) magnetic resonance imaging (fMRI), indicating that "the response of the mirror neuron system is strong intentional agents" (Rizzolatti, Fogassi, Gallese, 2006 , p 43).

"In social life as important as the perception of intention is understanding other people's emotions, they are often a key element of the context, indicating the intention to action". The study, therefore, unfolded further in the direction to check "whether the mirror neuron systems allow you to understand not only what others do, but also what they feel" (Rizzolatti, Fogassi, Gallese, 2006, p 43 and 44). The results show that the mirror neuron network located in the island is activated both when subjects are experiencing emotions themselves and when they observe other people and in the case of experiencing negative emotions activated in the front area of the island and the anterior cingulate gyrus.

Mirror neurons are active also in the process of imitation and "mirror neuron system if it is a bridge in this process and enables the understanding of human actions, intentions and emotions, perhaps in its development has become an important element of the human capacity for observation, based on the acquisition of advanced cognitive skills" (Rizzolatti, Fogassi, Gallese, 2006, p 45).

The researchers show that: "People with autism have a reduced activity of mirror neurons in the lower front corner, i.e., the premotor cortex of the brain, which may explain their inability to assess the intentions of others. Malfunctioning mirror neurons in the cortex of the island and the front of the rim of the brain can cause related symptoms, such as lack of empathy, and deficits in turn lead to angular language difficulties" (Ramachandran, Oberman, 2006, p 49). Ramachandran team from the University of California at San Diego to submit a further study (Society for Neuroscience, 2000), pointing at the involvement of mirror neurons in the observation process, and also linked it with common disorders in children with autism. Using electroencephalograph study measuring the brain waves produced in $\mu$, in the performance of simple hand movements conscious, and then measure the braking waves, $\mu$, which is the case with the analogous observation of the movements made by another person. As demonstrated above described studies in people with autism do not wave attenuation $\mu$ is the observation of movements performed by another person. Comparable results were obtained 
in the Helsinki University of Technology using magnetoencephalography and University of California, Los Angeles, using functional magnetic resonance imaging (Ramachandran, Oberman, 2006, p 51) - the results obtained, confirm the disturbances in the operation of mirror neurons in individuals with autism.

It seems, therefore, pertinent hypotheses that misunderstood intentions, emotions and non-reflecting nonverbal messages (body language, hand gestures, facial expressions, eye expression, modulation and pitch of their voices, including: volume, height, pace and rite sent the message) as the characteristic features of for people with autism, is closely linked to mirror neuron dysfunction - problems occurring in the course of observation. Drawing on the linguistic concepts can be identified for such, according to which interpersonal communication is triggered hand gestures and facial expressions - understanding without words, and it is properly functioning network of mirror neurons allow mirroring of actions, intentions and emotions so needed in communication.

But what is presented above give us the concepts, theories and research results? Certainly clarify the knowledge and above all help in the selection and conduct of therapy.

\section{In the "Arms" of Autism - Mary and Adam}

Mary was twenty-nine years old when I started with her therapeutic work. In preschool education, shortly before the start of the diagnosis - autism, then, in addition - a deep level of intellectual disability.

Mary's mother claimed that: "the development of his daughter would be much better if provided with the appropriate therapy in childhood".

In addition to being retard in intellectual development she had very severe behavioral, social development and communication problems. Thus, the behavior appeared in various forms of aggression directed at inanimate objects and animate (strong hitting her head on the head of another person, beating an open hand across the face - preserving such a patient / client was also demonstrated in relation to the therapists). There were also self-injurious behavior, manifested by biting of the fingers, the ball of his hand, hitting the open hand on the thighs and the head with her fists up to the states of visible injury. Mary also came to stereotypes, rocking in a sitting position as well as sniffing: items (mainly food), hands and other people - including their face, hair and even private parts. So Mary's social development was very much disturbed. Due to the above cited forms of aggressive behavior did not come with it in principle, associate with other people than your own immediate family, and those were often limited to contact with the mother. The woman never left alone at home, in public places did not comply with accepted legally, morally and customary rules of social behavior. In the 
stores she demolished the shelves, products, stealing, usually items for hair care and beauty of their (pins, hairpins and hair bands) - but I think that unfortunately did not understand the social and legal dimensions, the concept of "stealing" - she simply take off the shelves, what she liked to draw attention, or just what was at that time want to eat. Broke off and ate the fruit from trees and shrubs from the garden plots - mainly green immature fruits of apple and cherry. If, however, intellectual development did not allow her to understand the concept of theft and the consequences of its actions, it should would adhere to the ban: do not do that! - However, such prohibitions Mary did not respond to.

The woman does not respond well to traffic, she entered the roadway, went through it anywhere without paying attention to passing cars and caused concern. Parents tried to eliminate such behavior and above all an opportunity to reduce their manifestations, and deprives the social contact Mary and isolating it in the house - it seemed that at home it is more muted and less aggressive. The major difficulty in interpersonal interactions (which influenced the establishment of relationships and social development) was also a failure to communicate (such as verbal, nonverbal and alternate). However, Mary's mother claimed that her daughter communicates with her (but only with it) using the computer keyboard graphic version of drawn on cardboard. With Mary I tried to hold a dialogue with a real keyboard, to have insight on the computer screen in what she writes (with some of reasons classes were held at her home - during the class her mother was always present).

Below I place written statement (on the basis of forthcoming book: Trapped by autism).

May 18, 2008, the (second meeting) - Mary seemed to be excited. Her mother at one point stated that the daughter wants us to show on your computer. At my request: "Mary tell your story, leaving the house on the lake", the mother replied, "it was difficult for her, please ask a simpler question". I asked: "Are you pleased with the weekend away"? Mary nodded. During several minutes of classes - she wrote the computer keyboard: "gooooooo awwwwwaaaaayyy". Mary's mom said: "It's up to me". After leaving his mother Mary was unable to restrain emotions and self-harm, in the end she wrote: “ dooooooonnn'ttt wannnn". Demonstrated motor stereotypes and self-injurious behavior - ended because she was very aroused emotionally and try to reassure her not yielded results.

June 1, 2008, Mary was calm and wanted to start classes as soon as possible. I suggested that we talk in the first place (via computer), then go for a walk. Mary's mom added: "Daughter practiced playing the keyboard and would like to play, and then should go for a walk". I asked: "Do you want to go for a walk?" Mary wrote: “yeeeeeeeee ssssssssss". I asked: "How are you?" Mary wrote: “!!!!!!!!!” Mary's mum asked: "Are you afraid of something or something hurts you?" Mary: "huuurr mmmmmmmyyyyy lllleeeeeeee". I asked to be sure: "Does your leg hurt you?" She nodded. "Which leg?" - I asked. Mary wrote: "rgggggggggh". I asked 
the next question: "Tell me where do you want to go for a walk?" Mary's mom said: "We will go for the meads nearby". Mary wrote: "I tiiiiiiiiiiiiii rrrrrrrrr e dddddddd".

This was the communication with Mary and her level, social relationships were also specific, continuous behavioral disturbances, explosions, and the stereotype of a self-injury therapy is hampered.

Mary, however, never was aggressive towards me. On the contrary, she began to establish an emotional relationship and show empathy. The first attempt was to help in carrying my heavy bag when we went for a walk. Mary's mother said: "Should you leave this bag is too heavy". I joked that Mary will definitely help me to carry it, and surprisingly she came up to me in providing assistance. Mary's mother was surprised and said that it was her first such behavior in relation to another person. Mary was crying even after the end of the day, with good-byes, then hugged his mother, placed her head on her shoulder or under her arm.

Adam - twenty-three-year old men with the diagnosis - autism and profound intellectual disability.

Man unable to walk with conduct disorder manifesting primarily by stereotype - swaying from side to side in a sitting position, flapping his arms, sucking hands, constant crying. He calmed down when getting to suck a lollipop in the shape of the ball. He spoke only one word "mom", followed by an outburst from him crying. He cried if someone else was saying "mom" or when he was shown pictures of his mother. Crying was induced with him also in situations when he saw or heard other children crying. Mother claimed that her son at home often cries too, shakes and sways, then he wants to be hugged and cradled. This need was also manifested in the Special School, which came and satisfied when he calmed down, stopped crying. However, this behavior took place only for some people - not everyone could hug him and make him calm down.

Speech development was limited only to the word "mom" and different syllables repeated in the form of echolalia - a kind of vocalization, was little understood the message - was not supported by other not verbal communication.

To me, repeated sequences of syllables by Adam, uttered with characteristic intonation expressed his good mood and enjoyment, not shown through facial expressions. In the case of anxiety, fear and discontent he began to sway and cry - then needed a hug (even though it demanded in other situations). The word "mom" and her image evoked and perhaps longing for the mother - again relieved hugs. In any case, very often exhibited emotional behavior and showed a great need to meet the emotional needs of their own.

Mary maintained mentioned passive understanding of the messages and verbal commands but may not reach all of it, maybe not all of them she wanted to receive and respond only to some. Adam understood passive speech only at the level simple messages related primarily to the food intake, sometimes reacted to his name. Although the same diagnosis as to the intellectual development, were 
among those people, they determined differences in their intellectual abilities. Mary was under enormous impact her behavior disorders: self-injury and stereotypes and a lack of verbal communication and unwillingness to cooperate and execute any commands/tasks.

As with Mary and Adam, despite the huge deficits in cognitive and very serious problems: functioning, social development and the development of communication, there is a tendency to respond to emotional needs, there is empathy (with Mary) and imitation (Adam - in the case of emotional reactions).

\section{Summary and Conclusions}

Under current concept/theory and the available scientific data, accurate knowledge of the material world is closely connected with the transfer of information, or central coherence, and the development of empathy, the ability to understand the intentions and the intentions of others, the theory of mind and action of mirror neurons. On this basis, central coherence, as a function can be attributed to knowledge of the physical world/material, and the theory of the mind, exploring the world of the mental/human psyche. These two mechanisms operate independently: one that is theory of mind are neurologically conditioned, central coherence, perhaps genetically determined (Kruk-Lasocka, 1995) and as mentioned by other researchers in its functioning deficits arising from the micro-brain (Bragdon, Gamon, 2006) .

People with autism in addition to disturbances in the knowledge of the world (such as physical and mental) can be superimposed: hypersensitivity or lack of sensitivity in the reception of stimuli, and there may be disturbances in the form of signals from the body (Delacato, 1995). Defending against unwanted stimuli, attempts to organize the world, trying to rule over his own body and the outside world, among other things lead to stereotypes and/or ritual of behaviors.

And even if the autistic person manages to organize the material world by any, ritual observance, maintenance of constant objects in the environment and stereotyped behavior, it seems almost impossible to organize and understand the world of the human psyche, understanding intentional actions, emotional states, and the manifestation of empathy, without development of theory of mind and proper operation of the mirror neuron network.

Some people with autism regardless of the cognitive, the state of knowledge they have acquired and the level of practical skills can be seen sometimes small areas of exceptional ability. Such people can be very bad in the sphere of social and/or communication, but have unique talents such as musical, technical or mathematical. And even though they cannot acknowledge the fact that other people think differently, what else is interested, do not share their tastes, and it is difficult to imagine a state of mind of another man, but, like in case of islet talents, perhaps the skills in the receipt of the mental world, or parts of the world, may prove to be the only empathy shown is the one they want to show. Current results do not answer on this subject in a clear way (an attempt to assess the effectiveness 
of therapies based on current scientific data has, among others. M Suchowierska in paper: Effectiveness of applied behavior analysis in working with individuals with autism and related disorders in forthcoming publication: Time for the dialogue! Talk so effective revalidation, 2012).

Turning, therefore, attention to the therapeutic dimension, one cannot state that the effects are achieved through behavioral therapies. Indeed, there are changes in the functioning, social relationships and communication by individuals with autism, and thus in terms of their cognitive development, but I take the view that also very important are the therapies with emphasis on the emotional development of individuals with autism, especially in the emotional development of children. This is indicative of the current concepts of disorder in the development of the outline of that course of action and therapeutic skills in individuals with autism to read emotional messages and distinguish the degree of their expression as well as sending them to others as well as the development of empathy.

The discovery in the field of neuroscience in the form of mirror neuron dysfunction, impaired ability to give the effect of imitation (Rizzolatti, Fogassi, Gallese, 2006, p 45) also points to the need to exercise this function. The results of the least sensitive and critical periods in children (Blakemore, Frith, 2008) determine the most convenient time to take action, and their greatest therapeutic effectiveness, and example data, neuroplasticity of the brain (Blakemore, Frith, 2008; Domańska, Borkowska, 2008; Grabowska, 2008) bring some optimism about the possibilities of the human brain in the assimilation of lost functions and capabilities in the field of neuroscience.

Obtained results also contribute to the diagnosis of disorders in people with autism such as the discovery of mirror neuron activity and inhibition of $\mu$ wave in healthy subjects could be used as a diagnostic even with EEG.

The therapist does not get the final solution to the hand but knowledge which should be processed, adapted to the needs and abilities of the patient, patiently waiting for results of actions taken. In the case of therapies aimed at the development of the emotional effectiveness of their actions may depend on prevailing dysfunction, micro-or simply the functional maturity of the frontal lobes, and it is they, as the last in the brain, "waiting" with taking the full range of activities.

\section{References}

Blakemore S. J., Frith U. (2008). Jak uczy się mózg. Kraków: Wydawnictwo Uniwersytetu Jagiellońskiego.

Bobkowicz-Lewartowska L. (2005). Autyzm dziecięcy zagadnienia diagnozy i terapii. Kraków: Oficyna Wydawnicza Impuls.

Bowlby J. (2007). Przywiąanie. Warszawa: Wydawnictwo Naukowe PWN.

Bragdon A. D. (2003). Gamon D.: Kiedy mózg pracuje inaczej? Gdańsk: GWP. 
Delacato C. H. (1995). Dziwne, niepojęte. Autystyczne dziecko. Warszawa: Fundacja Synapsis.

Frith U. (2008). Autyzm. Wyjaśnienie tajemnicy. Gdańsk: GWP.

Grandin T., Scapiano M. M. (1995). Byłam dzieckiem autystycznym. Warszawa-Wrocław: Wydawnictwo Naukowe PWN.

Herzyk A. (2003). Mózg emocje uczucia. Analiza neuropsychologiczna. Lublin: Wydawnictwo Uniwersytetu Marii Curie-Skłodowskiej.

Herzyk A., Krukow P. (2008). Analiza neuropsychologiczna zaburzeń emocji i osobowości pacjentów z dysfunkcjami mózgu, [In:] Domańska, Ł., Borkowska, A. R. [Ed.]. Podstawy neuropsychologii klinicznej, p. 319-345. Lublin: Wydawnictwo Uniwersytetu Marii Curie-Skłodowskiej.

Holmes J. (2007). John Bowlby. Teoria przywiazania. Gdańsk: GWP.

Jaklewicz H (1993). Autyzm wczesnodziecięcy - diagnoza, przebieg, leczenie. Gdańsk: GTP.

Kruk-Lasocka J. (1999). Autyzm czy nie autyzm? Problemy diagnozy i terapii pedagogicznej matych dzieci. Wrocław: Wydawnictwo Dolnośląskiej Szkoły Wyższej Edukacji.

Piaget J. (2006). Jak sobie dziecko wyobraża świat? Warszawa: Wydawnictwo Naukowe PWN.

Pisula E. (2000). Autyzm u dzieci, diagnoza, klasyfikacja, etiologia. Warszawa: Wydawnictwo Naukowe PWN.

Pisula E. (1999). Dzieci autystyczne [In:] Obuchowska I. [Ed.]. Dziecko niepetnosprawne w rodzinie, p. 294-315. Warszawa: WSIP.

Pużyński S., Wiórka J. (1997). Klasyfikacja zaburzeń psychicznych i zaburzeń zachowania w ICD-10 opisy kliniczne i wskazówki diagnostyczne. Kraków-Warszawa: Uniwersyteckie Wydawnictwo Medyczne Vesalius.

Pużyński S., Wiórka J. (1998). Klasyfikacja zaburzeń psychicznych i zaburzeń zachowania w ICD10 badawcze kryteria diagnostyczne. Uniwersyteckie Wydawnictwo Medyczne Vesalius, Kraków-Warszawa.

Radochoński M. (1997). Zaburzenia osobowości w świetle amerykańskiej klasyfikacji DSM-IV [In:] Kostkiewicz J. [Ed.]: Szkice o ksztaltowaniu osobowości, p. 111-122. Wydawnictwo Wyższej Szkoły Pedagogicznej w Rzeszowie, Rzeszów.

Ramachandran V. S., Oberman L. M. (2006). Świat w rozbitym lustrze. Świat nauki, 12 (184), p. 47-53.

Rand B.: How To Understand People Who Are Different by Brad Rand. http://www.autism-pdd.net/ brad.htm. [30 październik 2010].

Rizzolatti G., Fogassi L., Gallese V.(2006). Zwierciadła umysłu, Świat nauki, 12 (184), s. 38-45.

Shreeve J. (2005). Umysł to efekt pracy mózgu. National Geographic, 3 (66), p. 2-31.

Smyczek A., Szwiec J. (2000). Poszukiwanie sposobów porozumiewania się [In:] Orkisz M., Piszczek M. i wsp. [Ed.]. Edukacja uczniów z głębokim upośledzeniem umysłowym. Przewodnik dla nauczycieli, p.55-64. Warszawa: Centrum Metodyczne Pomocy Psychologiczno-Pedagogicznej Ministerstwa Edukacji Narodowej.

Steuden M. (2008). Struktura i funkcje uktadu nerwowego [In:] Domańska Ł., Borkowska A. R. [Ed.]. Podstawy neuropsychologii klinicznej, p. 41-91. Lublin: Wydawnictwo Uniwersytetu Marii Curie-Skłodowskiej.

Wawrzyn K. (2007). Specyfika funkcjonowania osoby dotkniętej autyzmem - rola rodziny $w$ procesie wychowawczym $i$ terapeutycznym. Referat wygłoszony na Ogólnopolskiej Konferencji Naukowej pt.: Autyzm - wyzwania dla rodziny i społeczeństwa. Instytut Pedagogiki Specjalnej Dolnośląskiej Szkoły Wyższej we Wrocławiu, Wrocław.

Wawrzyn K. (2008). Zaburzenia postrzegania i przetwarzania informacji przez osobe autystyczna. Referat wygłoszony na Międzynarodowej Konferencji Naukowej pt.: Rain Man jest wśród nas. Współczesne formy pomocy osobom $\mathrm{z}$ autyzmem w ujęciu systemowym. Kraków: Akademia Pedagogiczna w Krakowie.

Wawrzyn K. (2009). Rozumienie komunikatów wysytanych przez dziecko z głęboka niepetnosprawnościa intelektualną. Warsztat prowadzony w ramach VI Zjazdu Rodzin Osób 
z Rzadkimi Zespołami Chromosomowymi. Stowarzyszenie Na Rzecz Dzieci z Zaburzeniami Genetycznymi GEN w Poznaniu, Poznań.

Wawrzyn K. (2010). Możliwości $w$ komunikacji werbalnej $i$ pozawerbalnej dzieci z głęboka niepetnosprawnościa intelektualna [In:] Wyczesany J. [Ed.]: Wspomaganie rozwoju dzieci z rzadkimi zespołami genetycznymi, p. 175-192. Poznań: Wydawnictwo Naukowe Polskiego Towarzystwa Pedagogicznego Oddział w Poznaniu.

Winczura B. (2008). Dziecko z autyzmem. Terapia deficytów poznawczych, a teoria umystu. Kraków: Oficyna Wydawnicza Impuls.

Zięba P. Tajemnica autyzmu. Strona Internetowa: http//bioinfo.mol.uj.edu.pl/articles/Zieba. [12 czerwiec 2011]. 